\title{
TRACING DISPERSED COALY-DERIVED PARTICLES IN MODERN SEDIMENTS: AN ENVIRONMENTAL APPLICATION OF ORGANIC PETROGRAPHY
}

\author{
S. KALAITZIDIS ${ }^{1}$ \\ K. CHRISTANIS ${ }^{1, *}$ \\ G. CORNELISSEN ${ }^{2,3}$ \\ O. GUSTAFSSON ${ }^{3}$
}

\author{
${ }^{1}$ Department of Geology, \\ University of Patras, 26500 Rio-Patras, Greece \\ ${ }^{2}$ Department of Environmental Engineering, \\ Norwegian Geotechnical Institute (NGI), \\ P.O. Box 3930 Ullevål Stadion, 0806 Oslo, Norway \\ ${ }^{3}$ Department of Applied Environmental Science (ITM), \\ Stockholm University, 10691 Stockholm, Sweden
}

*to whom all correspondence should be addressed: Fax: +30-2610997560

Received: 06/06/06 Accepted: 12/09/06 e-mail: christan@upatras.gr

\section{ABSTRACT}

A crucial aspect in environmental sciences is related to the transportation, accumulation and fate of solid organic particles not native to the sediments. In this study we present the petrographical features of seven sediment samples obtained from aquatic environments in Sweden, Finland and The Netherlands. Most of the samples represent the uppermost layers, which accumulated during the recent past. Their total organic carbon content ranges between 1.5 and $20 \%$. Density separations using heavy liquids were applied, in order to concentrate the organic matter and thus to facilitate the petrographical determinations. The microscopic approach revealed significant variations in the origin and hence, the type of the contained organic matter. Apart from modern plant debris and the algae indicating water-logged conditions, several particles of naturally and artificially derived solid-organic material were identified. The latter constitute organic contaminants, and include unburnt residues of highrank coals and chars. The petrographic data show a significant comparability with the 'black carbon' data determined by chemo-thermal oxidation at $375^{\circ} \mathrm{C}$, demonstrating the applicability of the microscopic analysis in environmental studies.
\end{abstract}

KEYWORDS: black carbon, char, fly ash, maceral, environmental organic petrography, solid coal contamination

\section{INTRODUCTION}

A significant field of environmental research concerns the contamination of the natural environment from industrial activities and particularly from the power generation sector. The contamination occurs in the form of either solid particles or diluted pollutants (hazardous and/or toxic organic and inorganic compounds) and originates from mining activities, storage (e.g. coal/lignite particles), processing and combustion (i.e. combustion derivatives, e.g. fly ash, unburned residues). The knowledge of the lateral dissemination of these contaminants and their distribution in the catchments is essential for planning remediation measures. Moreover, in some areas coaly particles constitute a significant portion of the modern soils and thus it is necessary to evaluate the fate of these contaminants within the natural ecosystem (e.g. Rumpel et al., 1998, Schmidt et al., 2000, Reyes et al., 2006).

There is a variety of chemical methods to characterize the organic matter in sediments (e.g. ${ }^{13} \mathrm{C}$-NMR). However, the heterogeneity of the organic constituents reduces the applicability of these methods. On the contrary, organic petrography techniques provide the optical characterization of the organic matter and can aid significantly to the determination of the kind 
and the features of various types of organic matter (both natural and anthropogenic) in sediments (Karapanagioti et al., 2000, 2001; Cornelissen et al., 2004; Ligouis et al., 2005).

In this study, the petrographic features of the organic matter contained in a set of modern sediments have been studied in order to estimate the degree of contamination from coaly particles. In this sense, the petrographic examination aims to distinguish between the modern organic matter (MOM) and the coal-derived organic matter (CDOM). The petrographic data are evaluated in conjunction to chemical data such as the black carbon content (BC) and the age of the organic matter and black carbon as determined by ${ }^{14} \mathrm{C}$ dating.

\section{MATERIALS AND METHODS}

Seven samples of lake sediments from Finland, The Netherlands and Sweden were obtained by grab sampling (Table 1). Due to their low organic matter contents, density separation was applied using a $\mathrm{ZnCl}_{2}$ solution with a density of $1.8 \mathrm{~g} \mathrm{~cm}^{3}$. The light fraction was skimmed, dried and then impregnated in epoxy resin in cylinder mounts. Polished blocks were prepared according to standard coal-petrography techniques and microscopic observation was conducted under incident white light and blue-light excitation (Taylor et al., 1998). Moreover, the ash yield was determined after combustion at $550^{\circ} \mathrm{C}$.

Table 1. Location of the samples.

\begin{tabular}{llrccc}
\hline \multicolumn{1}{c}{ Location } & Notation & \multicolumn{2}{c}{ Coordinates } & Environment & $\begin{array}{c}\text { Sampling } \\
\text { depth }(\mathrm{m})\end{array}$ \\
\hline Mekrijärvi, Finland & MEK & $62^{\circ} 45^{\prime} \mathrm{N}$ & $30^{\circ} 57^{\prime} \mathrm{E}$ & Mire lake & 1.6 \\
Slussen, Sweden & SLS & $59^{\circ} 32^{\prime} \mathrm{N}$ & $18^{\circ} 06^{\prime} \mathrm{E}$ & City harbour & 5 \\
Kuorinka, Finland & KUO & $62^{\circ} 37^{\prime} \mathrm{N}$ & $29^{\circ} 23^{\prime} \mathrm{E}$ & Lake & 8 \\
Tyresta 1, Sweden & TYR 1 & $59^{\circ} 22^{\prime} \mathrm{N}$ & $18^{\circ} 16^{\prime} \mathrm{E}$ & Forest lake & 20 \\
Tyresta 3, Sweden & TYR 3 & $59^{\circ} 22^{\prime} \mathrm{N}$ & $18^{\circ} 16^{\prime} \mathrm{E}$ & Forest creek & 3 \\
Stora Värtan, Sweden & STV & $59^{\circ} 41^{\prime} \mathrm{N}$ & $18^{\circ} 12^{\prime} \mathrm{E}$ & Brackish fjord & 15 \\
Ketelmeer, & $\mathrm{KET}$ & $52^{\circ} 36^{\prime} \mathrm{N}$ & $5^{\circ} 45^{\prime} \mathrm{E}$ & Estuarine lake & 3 \\
The Netherlands & $\mathrm{K}$ & & & & \\
\hline
\end{tabular}

According to the internationally accepted classification (ICCP, 1963; 1971; 1998; 2001; Sýkorová et al., 2005), the individual organic constituents being recognizable under the microscope are defined as macerals. The latter are distinguished in three main groups: a) Huminite that originates mainly from humic plant material, rich in cellulose and lignin, such as stems, roots etc.; the term Huminite is applied for recent organic matter (Kalaitzidis and Christanis, 2000) up to the rank stage of sub-bituminous coal, whereas at higher coalification stages (bituminous coal to anthracite) the term vitrinite is used instead (ICCP, 1998), b) Liptinite, which originates from hydrogen-rich plant remnants such as spores, resins, waxes etc., and c) Inertinite that includes oxidized macerals, as well as fungal remains. Under white reflected light, Inertinite displays the highest and Liptinite the lowest reflectance. The macerals of the liptinite group are identified under blue light excitation, under which they fluoresce. Maceral analysis, i.e. quantification of the maceral composition of all the samples, has been performed using a LEICA DMRX coal-petrography microscope equipped with both white incident light and fluorescence modes (magnification 500X, oil immersion) and point counting. On the surface of each polished block, 500 macerals were identified and counted.

Total Organic Carbon (TOC) contents were determined using a procedure (Gustafsson et al., 2001) in which $10 \mathrm{mg}$ dried (at $60^{\circ} \mathrm{C}$ ) and ground sediment is first subjected to in-situ microacidification $(30 \mu \mathrm{L} 1 \mathrm{M} \mathrm{HCl})$ and then analyzed with catalytic combustion elemental analysis at $1030^{\circ} \mathrm{C}$ (Carlo Erba model 1106). Black carbon (BC) content was measured as follows; combustion at $375^{\circ} \mathrm{C}$ followed by in-situ acidification with $1 \mathrm{M} \mathrm{HCl}(30 \mu \mathrm{L}$ per $10 \mathrm{mg}$ sediment) was employed in order to create a sediment with only BC but no other organic or inorganic carbon. This "CTO 375" method has elaborately been described and tested (Gustafsson et al., 1997; 2001; Accardi-Dey and Gschwend, 2002). Dry and finely ground sediment (10 mg in Ag capsules) was heated at $375 \pm 2^{\circ} \mathrm{C}$ during $18 \mathrm{~h}$ under a constant air flow of $200 \mathrm{~mL} \mathrm{~min}^{-1}$. A small sample size was employed to optimize access of oxygen to the sediments, which is important to prevent charring. The BC contents of the sediments are 
measured as TOC of the combusted residues, in the way described above. Also, the ${ }^{14} \mathrm{C}$ contents of the BC were determined using Accelerator Mass Spectrometry (AMS) at Woods Hole Oceanographic Institute (WHOI), following the procedures outlined in Reddy et al. (2002). The results of the ${ }^{14} \mathrm{C}$ analyses are presented as "fraction contemporary" $\left(f_{\mathrm{C}}\right)$. Generally, the $f_{\mathrm{C}}$ represents the "modern" fraction of BC that stems from biomass combustion. The other "fossil" fraction of $\mathrm{BC}\left(1-f_{\mathrm{C}}\right)$ then derives from fossil fuel combustion and contains no ${ }^{14} \mathrm{C}$.

\section{RESULTS AND DISCUSSION}

The studied samples contain low to moderate values of organic matter, as revealed from the ash yields and the TOC concentrations (Table 2). In terms of black carbon (BC) samples KET and KUO contain the higher amounts and MEK the lowest, as obtained from BC/TOC ratio.

Table 2. Ash, Total Organic Carbon (TOC) and Black Carbon (BC) contents of the samples, as well as the fractions of "contemporary" $\left(f_{\mathrm{C}}\right)$ and "fossil" carbon $\left(f_{\mathrm{F}}\right)$.

\begin{tabular}{lccccccc}
\hline \multicolumn{1}{c}{ SAMPLE } & MEK & SLS & KUO & TYR 1 & TYR 3 & STV & KET \\
\hline Ash $\left(550^{\circ} \mathrm{C}\right)$ & 64 & 84 & 97 & - & 72 & 87 & 90 \\
\hline TOC $(\%)$ & 20 & 8.8 & 1.5 & 11.8 & 13.7 & 5.8 & 5.5 \\
\hline BC $(\%)$ & 0.1 & 0.3 & 0.15 & 0.2 & 0.26 & 0.23 & 0.72 \\
\hline BC/TOC $(\%)$ & 0.4 & 3.4 & 10.0 & 1.7 & 1.9 & 4.0 & 13.1 \\
\hline$f_{\mathrm{C}}$ BC $(\%)^{\mathrm{a}}$ & 49 & 36 & 15 & 57 & 59 & 61 & 18 \\
\hline$f_{\mathrm{F}} \mathrm{BC}(\%)^{\mathrm{a}}$ & 51 & 64 & 85 & 43 & 41 & 39 & 82
\end{tabular}

${ }^{a} f_{\mathrm{C}}$ represents the "modern" fraction of carbon (TOC or $\mathrm{BC}$ ) that stems from biomass combustion. The "fossil" fraction $\left(f_{\mathrm{F}}=1-f_{\mathrm{C}}\right)$ derives from fossil fuel combustion and contains no ${ }^{14} \mathrm{C}$.

The results of the ${ }^{14} \mathrm{C}$ analyses, presented as "fraction contemporary" $\left(f_{\mathrm{C}}\right)$ and "fossil fraction" $\left(f_{\mathrm{F}}\right)$ provide the age of $\mathrm{BC}$, and subsequently are used to assess the origin of the condensed organic matter. In samples KUO, KET and SLS the "fossil fraction" of BC predominates $\left(f_{\mathrm{F}} \mathrm{BC}\right.$ $>60 \%$ ), in sample MEK "modern and fossil fractions" are almost equal, whereas in samples TYR 1, TYR 3 and STV the modern fraction of BC predominates (Table 2).

The microscopic examination of the organic matter contained in sediments primarily provides information concerning the origin of the organic matter, as well as the alteration pathways (e.g. humification) that the organic matter has undergone. According to the qualitative and the quantitative microscopical characteristics (maceral composition, see Table 3), the organic matter of the samples is divided within two categories: modern organic matter (MOM) and contaminating coaly-derived organic matter (CDOM). MOM includes terrestrial plant debris, as well as aquatic elements (e.g. algae), whereas CDOM includes coal particles, which can originate either from industrial utilizations (e.g. mines, power plants) or from erosion of naturally outcropping coal seams.

\section{Origin of organic matter}

Concerning the MOM, the petrographic results point out that huminite is the prevailing maceral group in all the samples, except in the STV sample, in which liptinite predominates (Fig. 1a). The predominance of humic organic matter indicates that the major part of the recent organic matter originated from terrestrial plants. Moreover, the recent organic matter in most of the samples is intensely fragmented and occurs as attrinite (i.e. fragments of humic tissues with $\varnothing<10 \mu \mathrm{m}$ ). The predominance of attrinite is reasonable, since the organic matter underwent transportation from outside the lake. Consequently, the preservation of the initial plant-cell structure, as indicated by textinite values, is rather low. Textinite occurs with significant values only in TYR3 sample, probably due to the fact that forest woody tissues, which are more resistant to degradation than the herbaceous ones, were deposited in the creek environment. Moderate frequency of textinite was revealed in the lake sediments MEK and KUO, representing mainly tissues of root systems. The high alginite content of sample 
STV coincides with the fact that deposition took place in a brackish environment, where algae mostly thrived (Fig. 1a, b).

Table 3. Maceral composition of the organic fraction (on dry, mineral matter-free basis).

\begin{tabular}{|c|c|c|c|c|c|c|c|}
\hline SAMPLE & MEK & SLS & KUO & TYR 1 & TYR 3 & STV & KET \\
\hline \multicolumn{8}{|c|}{ MACERAL COMPOSITION (in 100 vol.-\% organic matter of the light fraction) } \\
\hline \multicolumn{8}{|l|}{ MOM } \\
\hline Pre-textinite ${ }^{a}$ & 13.0 & 0.8 & 9.2 & & 19.4 & 3.4 & 5.0 \\
\hline Textinite A & 2.2 & & 2.8 & 2.0 & 2.4 & & \\
\hline Pre-texto-ulminite ${ }^{a}$ & 0.4 & 2.8 & 0.8 & & & & \\
\hline Texto-ulminite & 1.6 & & 2.4 & 2.4 & 1.4 & 0.8 & 3.0 \\
\hline Pre-eu-ulminite ${ }^{a}$ & & 1.6 & & & 0.6 & & \\
\hline Eu-ulminite & & & 0.8 & 0.4 & & & \\
\hline Telohuminite & 17.2 & 5.2 & 16.0 & 4.8 & 23.8 & 3.2 & 8.0 \\
\hline Attrinite & 60.2 & 68.8 & 54.8 & 55.8 & 49.0 & 38.8 & 22.4 \\
\hline Densinite & 3.8 & 1.4 & 1.6 & & 0.4 & 1.2 & 1.2 \\
\hline Detrohuminite & 64.0 & 70.2 & 56.4 & 55.8 & 49.4 & 40.0 & 23.6 \\
\hline Porigelinite & 0.6 & 0.8 & 0.8 & & 3.6 & 0.8 & 0.8 \\
\hline Levigelinite & 0.8 & 1.4 & 1.2 & 3.0 & 1.0 & & 1.2 \\
\hline Corpohuminite & 0.2 & 0.4 & 0.4 & 0.2 & 0.8 & 0.4 & 1.2 \\
\hline Gelohuminite & 1.6 & 2.6 & 2.4 & 3.2 & 5.4 & 1.2 & 3.2 \\
\hline Total Huminite & 80.8 & 78.0 & 73.2 & 63.8 & 75.6 & 44.0 & 34.8 \\
\hline Fusinite & 0.2 & & 0.2 & 0.4 & 0.2 & 0.6 & \\
\hline Semifusinite & 0.4 & 0.8 & 0.4 & 0.2 & 0.4 & 0.4 & 3.0 \\
\hline Funginite & 0.2 & 1.0 & 0.2 & 0.8 & 0.6 & 0.8 & 0.4 \\
\hline Inertodetrinite & 0.2 & 2.6 & 1.2 & 1.6 & 0.6 & 1.6 & 2.0 \\
\hline Total Inertinite & 1.0 & 4.4 & 2.0 & 3.0 & 1.8 & 3.4 & 5.4 \\
\hline Sporinite & 6.6 & 0.4 & 13.0 & 10.8 & 9.2 & 17.4 & 1.4 \\
\hline Cutinite & 1.2 & 1.0 & 2.2 & 2.8 & 1.0 & 1.2 & 0.4 \\
\hline Resinite & & 0.8 & & & & & 0.2 \\
\hline Suberinite & 0.2 & 0.2 & 1.0 & 0.2 & 2.2 & 0.2 & 0.4 \\
\hline Alginite & 1.6 & & 2.8 & 6.6 & 0.4 & 23.4 & \\
\hline Liptodetrinite & 6.2 & 0.6 & 3.8 & 11.4 & 6.6 & 5.8 & \\
\hline Amorphinite & 0.4 & 0.6 & 0.4 & 0.8 & 0.2 & 3.2 & \\
\hline Total Liptinite & 16.2 & 2.4 & 23.2 & 33.2 & 19.6 & 51.2 & 0.8 \\
\hline \multicolumn{8}{|l|}{ CDOM } \\
\hline$\overline{\text { Telinite }}$ & & 1.0 & & & & & 5.4 \\
\hline Collotelinite & & 5.6 & & & & & 31.6 \\
\hline Collodetrinite & & 1.0 & & & & & 3.0 \\
\hline Gelinite & & 1.0 & & & & & 2.0 \\
\hline Total Vitrinite & & 8.6 & & & & & 42.0 \\
\hline Chars & & 4.4 & & & & & 8.6 \\
\hline Inertinite ${ }^{b}$ & & 1.0 & & & & & 6.8 \\
\hline Liptinite $^{b}$ & & 1.2 & & & & & 1.6 \\
\hline Total CDOM & & 15.2 & & & & & 59.0 \\
\hline Carbonized OM ${ }^{\mathrm{C}}$ & 0.8 & 8.8 & 1.8 & 2.2 & 1.2 & 2.6 & 20.4 \\
\hline
\end{tabular}

a: The prefix 'pre-' denotes fresh (unhumified) organic matter.

b: Included in vitrinites.

c: Carbonized organic matter $=$ Char + Inertinite (except funginite, which derives from fungi and did not undergo carbonization). 
The alteration degree of the organic matter sensu humification and/or gelification can be inferred from the reflectance and fluorescence characteristics, as well as from the presence of the macerals ulminite, densinite and gelinite. In general, the organic matter of the studied sediments is only poorly gelified. In most cases, textinite occurs with red internal reflections and displays intense fluorescence due to the preservation of cellulose residues. Only samples TYR1 and TYR3 reveal a relatively higher humification degree (i.e. production of humic colloids, gelinite), as the result of the forest environment. Another process that can be identified through the petrographic approach concerns the oxidation of the organic matter. The inertinite group represents the macerals that originate from oxidation (e.g. fires) of organic tissues or from the aerobic fungal remnants (i.e. funginite). In the studied samples inertinite occurs in low amounts $(<3.4 \%)$, with inertodetrinite and fusinite displaying almost equal contents.

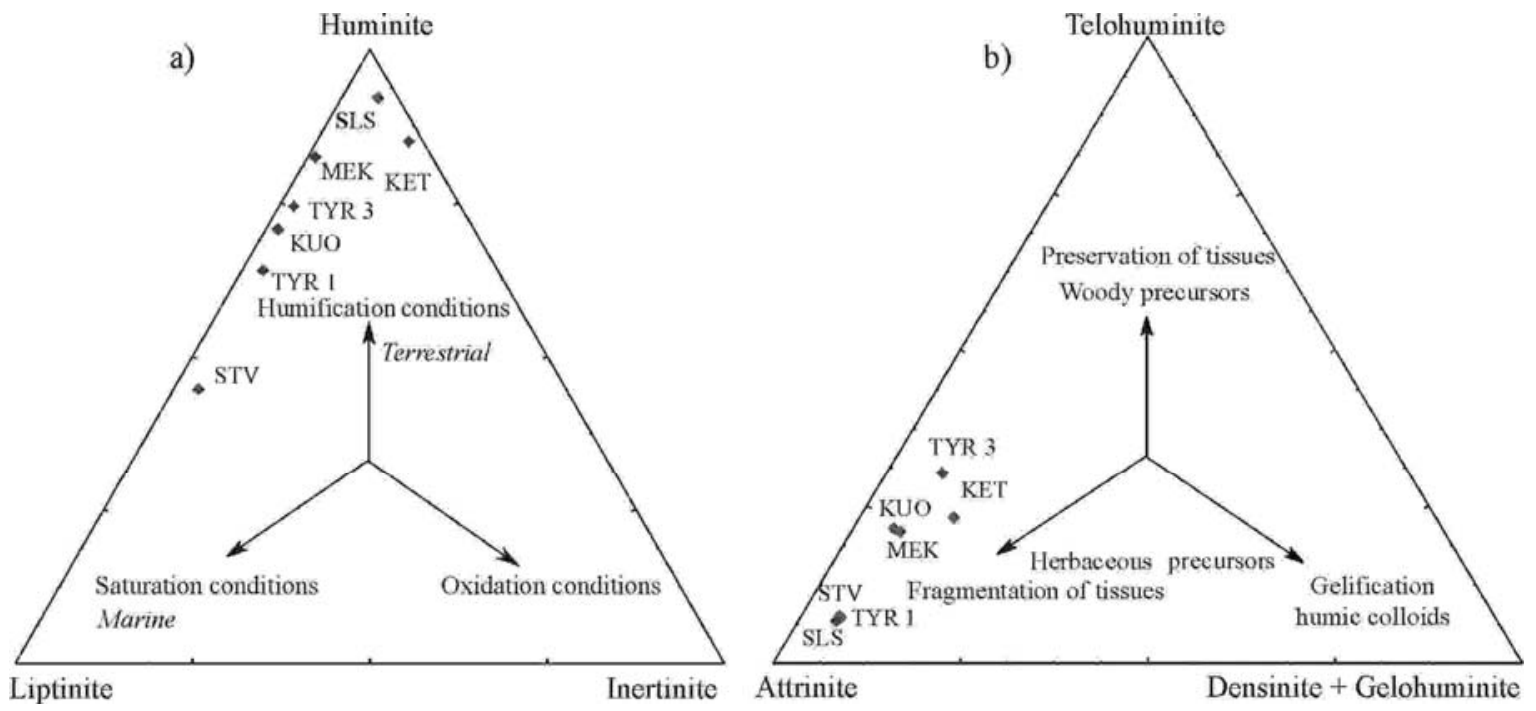

Figure 1. Ternary plots of the maceral analyses results.

\section{Not native coaly-derived organic matter}

Apart from the modern organic matter, the microscopic observation revealed the occurrence of coaly-derived organic matter within the SLS and KET samples (Fig. 2), which as pointed above contain significant amounts of BC. The identified particles can be grouped in two categories: 1) hard-coal particles, and 2) carbonized coal particles, i.e. chars. In the hard-coal particles, the usual maceral groups (vitrinite, liptinite and inertinite) have been recognized; vitrinite represents the coalification product of huminite, and is distinguished by its higher reflectance compared to huminite, whereas the macerals of liptinite and inertinite groups are similar to that of the recent organic matter. The co-occurrence of vitrinite and chars indicates that the coaly-derived particles represent solid contaminants of coal-combustion power plants.

Maceral analysis revealed that sample KET contains 42 vol.- $\%$ of vitrinite, mainly as collotelinite, and 8.6 vol.- $\%$ of chars (Table 3). The cumulative content of coaly-derived organic matter for sample KET is 59 vol.-\%, indicating severe contamination. The Ketelmeer freshwater lake is a sedimentation area of the Rhine River. The shores of this river are densely populated and heavily industrialized. Additionally, large-scale coal mining activities for power generation used to take place. The percentage of coal-derived particles in sample SLS reaches up to 15.2 vol.-\%, also represented mostly by vitrinite particles. It is noteworthy to mention that micrinite, a maceral of the inertinite group that occurs only in hard coals, was identified within vitrinites of KET sample. Additionally, inertodetrinite as well as secretinite was contained within collodetrinite. Furthermore, the vitrinite of both KET and SLS samples included macerals of the liptinite group such as bodies of resinite and sporinite (Table 3). 


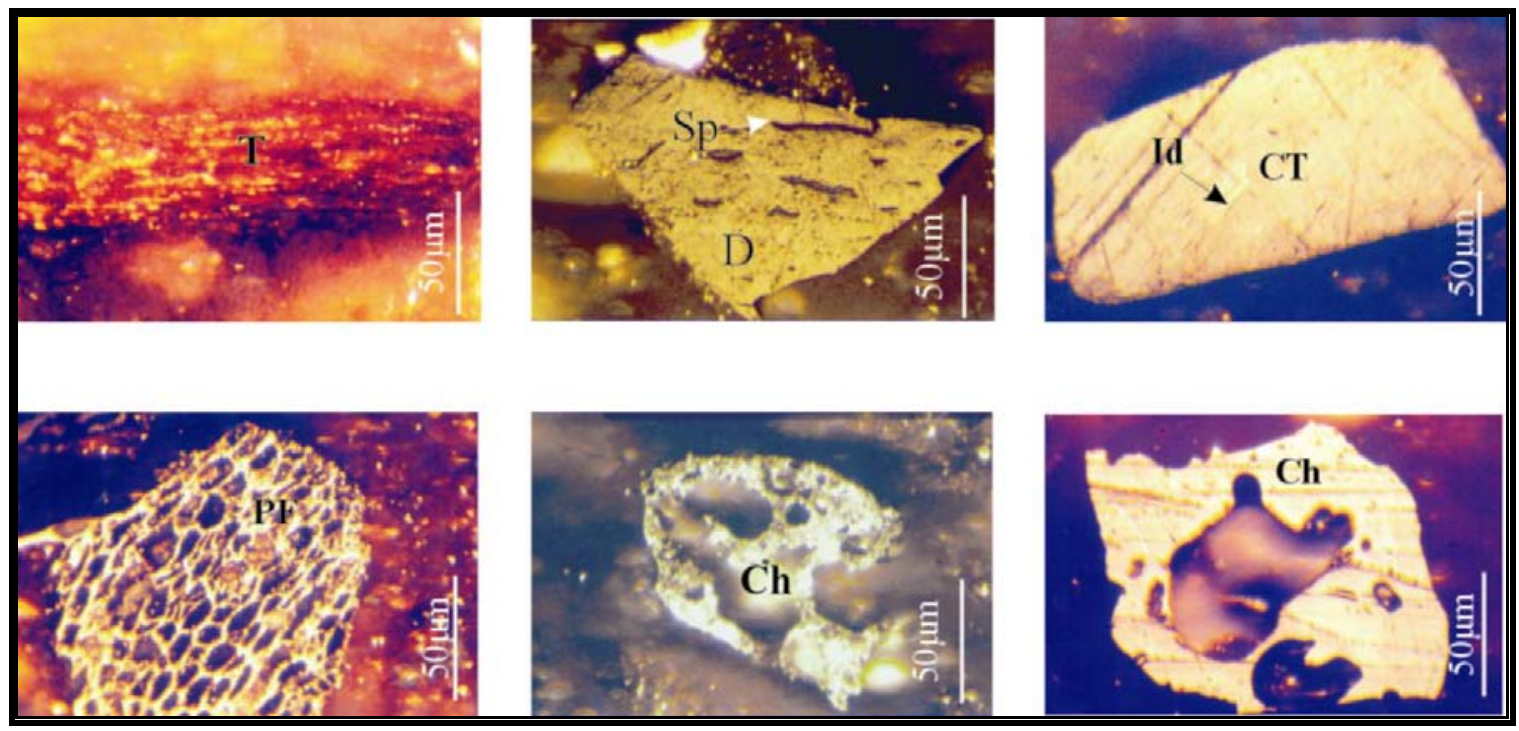

Figure 2. Photomicrographs of the identified macerals, under white reflected light (Ch: char, CT: collotelinite, D: collodetrinite, Id: inertodetrinite, PF: pyrofusinite, Sp: sporinite, T: textinite).

\section{Comparison between organic petrographical data and chemical data}

An important aspect is to evaluate the comparability between the petrographic and the chemical applications for determining modern contamination. In this sense the $\mathrm{BC}$ and $f_{\mathrm{F}}(\mathrm{BC})$ are correlated with the fraction of carbonized organic matter, which is defined as the sum of char and inertinite (except funginite) (Figure 3, Tables 2 and 3). The regression analysis (Figure 3 ) indicates that in general there is a good agreement between the parameters BC, "fossil fraction" of BC and carbonized OM. Only sample KUO diverges significantly; the reason for this divergence could be analytical restrictions, e.g. very fine-grained substances lost during density separations. Nevertheless, further studies are required towards the correlation of petrographical and chemical data, in order to better understand the relevant relationship.
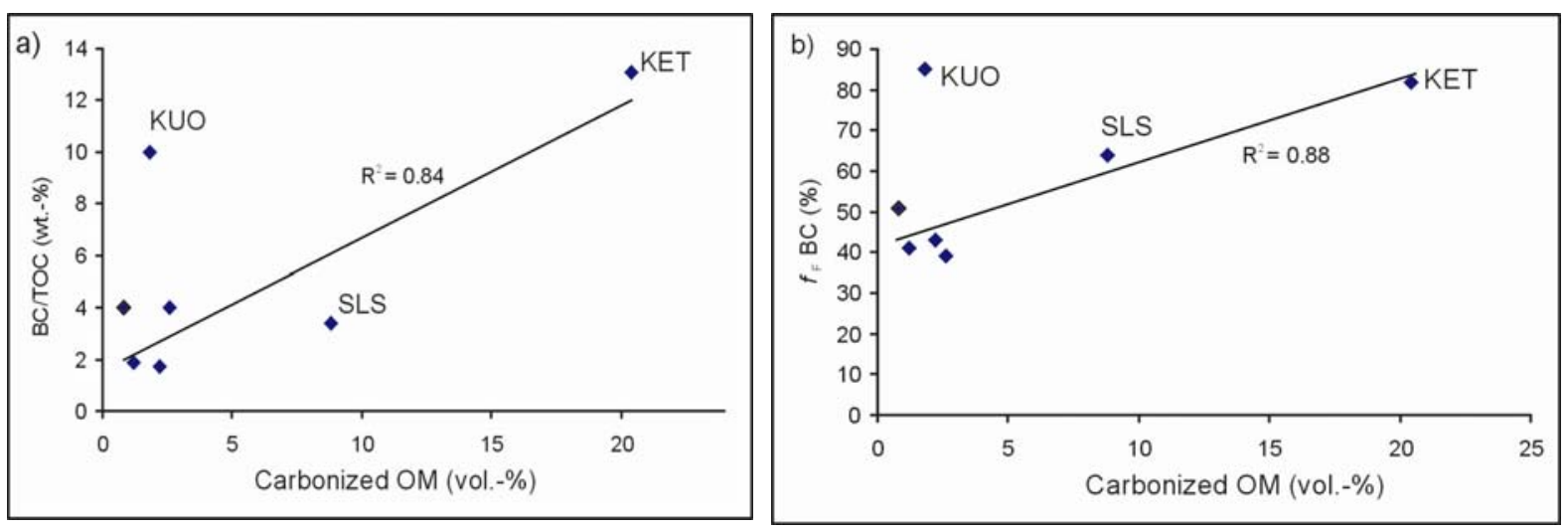

Figure 3. Regression analysis between the petrographical and the chemical data (KUO sample is ignored).

\section{CONCLUSIONS}

The results of this study prove that coal-petrographic examinations can be useful in assessing the environmental impact of coal-mining and coal-burning activities on lake environments. It has been demonstrated that in North-European lakes, organic remnants of different origins have been trapped within the sediments. The organic matter corresponds to modern plant remnants of various humification and oxidation degrees, algae and fungi, as well as to unburned coal and carbonized particles (chars). It is believed that the quantification of the 
various types of organic tissues under the microscope, in combination to chemical data, can be an important tool in evaluating contamination of soils and sediments from air- and waterborne coal-derived particles.

\section{REFERENCES}

Accardi-Dey, A. and Gschwend, P.M. (2002), Assessing the Combined Roles of Natural Organic Matter and Black Carbon as Sorbents in Sediments, Environ. Sci. Technol., 36, 21-29.

Cornelissen, G., Kukulska, Z., Kalaitzidis, S., Christanis K. and Gustafsson, Ö. (2004), Relations between environmental black carbon sorption and geochemical sorbent characteristics, Environ. Sci. Technol., 38, 3632-3640.

Gustafsson, Ö., Bucheli, T.D., Kukulska, Z., Andersson, M., Largeau, C., Rouzard, J.N., Reddy, C.M. and Eglinton, T.I. (2001), Evaluation of a protocol for the quantification of black carbon in sediments, Global Biogeochem. Cycles, 15, 881-890.

Gustafsson, Ö., Haghseta, K., Chan, F. McFarlane, A. and Gschwend, P.M. (1997), Quantification of the Dilute Sedimentary Soot Phase: Implications for PAH Speciation and Bioavailability, Environ. Sci. Technol., 31, 203-209.

International Committee for Coal Petrology (ICCP) (1963), International Handbook of Coal Petrography, $2^{\text {nd }}$ edition. Centre National de la Recherché Scientifique, Paris, France.

International Committee for Coal Petrology (ICCP) (1971), International Handbook of Coal Petrography, $1^{\text {st }}$ supplement to $2^{\text {nd }}$ edition. Centre National de la Recherché Scientifique, Paris, France.

International Committee for Coal and Organic Petrology (ICCP) (1998), The new vitrinite classification (ICCP System 1994), Fuel, 77, 349-358.

International Committee for Coal and Organic Petrology (ICCP) (2001), The new inertinite classification (ICCP System 1994), Fuel, 80, 459-471.

Kalaitzidis, S. and Christanis, K. (2000), Petrography, mineralogy and geochemistry of the Holocene peat of the Philippi peatland, Hellas: Preliminary results, in, Sustaining our Peatlands, Proc. $11^{\text {th }}$ International Peat Congress, August 6-12, 2000, Québec, Canada, by L. Rochefort and J.Y. Daigle (eds), vol 2, 593-603.

Karapanagioti, H.K., Kleineidam, S., Sabatini, D.A., Grathwohl, P. and Ligouis, B. (2000), Impacts of Heterogeneous Organic Matter on Phenanthrene Sorption: Equilibrium and Kinetic Studies with Aquifer Material, Environ. Sci. Technol., 34, 406-414.

Karapanagioti, H.K., Childs, J. and Sabatini, D.A. (2001), Impacts of Heterogeneous Organic Matter on Phenanthrene Sorption: Different Soil and Sediment Samples, Environ. Sci. Technol., 35, 4684-4690.

Ligouis, B., Kleineidam, S., Karapanagioti, H.K., Kiem, R., Grathwohl, P. and Niemz, C. (2005), Organic petrology: a new tool to study contaminants in soils and sediments, in Environmental Chemistry, by E. Lichtfouse, S. Dudd, and D. Robert (Eds.), Springer Verlag, Berlin.

Reddy, C.M., Pearson, A., Xu, L., McNichol, A.P., Benner Jr, B.A., Wise, S.A., Klouda, G.A., Currie, L.A. and Eglinton, T.I. (2002), Radiocarbon as a tool to apportion the sources of polycyclic aromatic hydrocarbons and black carbon in environmental samples, Environ. Sci. Technol., 36, 1774-1782.

Reyes, J., Goodarzi, F., Sanei, H., Stasiuk, L.D. and Duncan, W. (2006), Petrographic and geochemical characteristics of organic matter associated with stream sediments in Trail area British Columbia, Canada, Int. J. Coal Geol., 65, 146-157.

Rumpel, C., Knicker, H., Kögel-Knabner, I., Skjemstad, J.O. and Hüttl, R.F. (1998), Airborne contamination of immature soil (Lusatian mining district) by lignite-derived material: its detection and contribution to the soil organic matter, Wat. Air Soil Pollut., 105, 481-492.

Schmidt, M.W.I., Knicker, H., Hatcher, P.G. and Kögel-Knabner, I. (2000), Airborne contamination of forest soils by carbonaceous particles from industrial coal processing, J. Environ. Quality, 29, 768-777.

Sýkorová, I., Pickel, W., Christanis, K., Wolf, M., Taylor, G.H. and Flores, D. (2004), Classification of huminite - ICCP System 1994, Int. J. Coal Geol., 62, 85-106.

Taylor, G.H., Teichmüller, M., Davis, A., Diessel, C.F.K. Littke, R. and Robert, P. (1998), Organic Petrology, Gebrüder Borntraeger, Berlin-Stuttgart. 